\title{
Astragalus neurocarpus Bioss. as a potential source of natural enzyme inhibitor associated with Alzheimer's and Parkinson diseases along with its rich polyphenolic content and antioxidant activities
}

\author{
Nazim Sekeroglu **** and Sevgi Gezici**,*** \\ *Department of Food Engineering, Faculty of Engineering and Architecture, Kilis 7 Aralik University, 79000, \\ Kilis, Turkey. \\ **Advanced Technology Application and Research Center, Kilis 7 Aralik University, 79000, Kilis, Turkey. \\ ***Department of Molecular Biology and Genetics, Faculty of Arts and Sciences, Kilis 7 Aralik University, 79000, \\ Kilis, Turkey.
}

Received April 25, 2019: Revised June 10, 2019: Accepted June 12, 2019: Published online June 30, 2019

\begin{abstract}
Astragalus neurocarpus Bioss. (AN), a member of the Fabaceae family, is a traditional medicinal plant that its root parts have been known as strengthening the immune system. As far as our literature survey could ascertain, enzyme inhibitory activity, free radical scavenging and reducing antioxidant power activities of AN have not been reported elsewhere previously. Therefore, the present study was performed to assess total polyphenolic contents, antioxidant activities and neuroprotective potentials of the ethanol and water extracts from aerial part and root of the plant.Total phenol and flavonoid contents of the extracts were determined spectrophotometrically. Antioxidant activity was analysed by using in vitro DPPH, ABTS, FRAP and CUPRAC assays. Neuroprotective activities of the extracts were assessed through enzyme inhibition on AChE, BChE and TYR. Regarding of total phenol and flavonoid quantities, all the extracts obtained from the aerial parts possessed higher polyphenolic contents, when compared to the root extracts. Ethanol extract prepared from the aerial parts of the plant were found the highest amount of total flavonoid quantity $(179.34 \pm 1.02 \mathrm{mg} / \mathrm{g}$ extract, as $\mathrm{QE})$, while ethanol extract prepared from the root part possessed the lowest amount of total flavonoid quantity $(49.73 \pm 1.56 \mathrm{mg} / \mathrm{g}$ extract, as QE). The tested extracts were found to have higher inhibition against cholinesterase enzymes than those of the tyrosinase enzyme. Cholinesterase inhibitory activity assays on $\mathrm{AChE}$ and $\mathrm{BChE}$ enzymes were resulted in the superiority of the ethanol extracts obtained from the aerial parts $(68.14 \pm 0.03 \%$ and $59.44 \pm 1.02 \%$ inhibition, respectively). According to antioxidant assays, all the extracts obtained from different parts of the plant exhibited remarkable activities on DPPH, ABTS and FRAP, whilst they were moderate effects on CUPRAC.
\end{abstract}

Keywords: Astragalus neurocarpus Bioss., neuroprotective, polyphenolic content, antioxidant, enzyme inhibition

\section{Introduction}

Among the people, there has been a widespread interest in usage of the natural antioxidants in order to prevent oxidative stress related to diseases recently. Fighting the free radicals occurring in the human body is one of the most effective prevention strategy in most oxidative-stress related diseases including cancer, cardiovascular disease, chronic kidney diseases, diabetes, rheumatoid arthritis atherosclerosis, and neurodegenerative diseases (Newman and Cragg, 2016; Gezici, 2018; Gezici, 2019; Gezici and Sekeroglu, 2019a).

There are many natural herbal products and formulations, obtained from medicinal plants, with high antioxidant capacities for fighting free radicals around the world (Iqbal, 2013; Biradar, 2015; Gezici

\footnotetext{
Author for correspondence: Dr. Nazim Sekeroglu Professor, Department of Food Engineering, Faculty of Engineering and Architecture, Kilis 7 Aralýk University, 79000, Kilis, Turkey. E-mail: nsekeroglu@gmail.com, sekeroglu@kilis.edu.tr Tel.: +90-5324015512

Copyright () 2019 Ukaaz Publications. All rights reserved.

Email: ukaaz@yahoo.com; Website: www.ukaazpublications.com
}

and Sekeroglu, 2019a). Among these medicinal plants, Astragalus (Fabaceae family) species are well-known plant group and of important antioxidant source. This genus has many valuable species which have been used for immunostimulant, hepatoprotective, antiviral, antioxidative, wound-healing, anti-depressive, and antiinflammatory properties in folk medicine (Block and Mead, 2003; Gülcemal et al., 2013; Roleira et al., 2018). Members of this genus are rich in secondary metabolites such as polysaccharides, saponins, indolizidine alkaloids, flavones and cycloartanes, which are closely linked to their wide range of biological activities (Rios and Waterman, 1997; Ionkova et al., 2014).

Previously, root extracts of $A$. memdranaceus, A. sieversianus and A. mongholicus have been screened for their biological activities and their protective effects against liver damage were reported using in vivo rat and mouse models (Zhang et al., 1992; Wang and Han, 1992). There are valuable scientific reports performed both in vitro and in vivo conditions, approving good biological activities, Astragalus species with distinguished phytochemical compositions. Liu et al. (2018) demonstrated in animal model that Astragalus 
polysaccharides (APS) had good therapeutic effect in the treatment of neurodegenerative diseases and nerve injury disease. Labed $e t$ al. (2016) studied phytochemical composition and biological activities of Astragalus armatus Willd. subsp. numidicus (Fabaceae) pods, an endemic shrub of Maghreb. They found that ethyl acetate extract afforded a flavonoid (1) while the n-butanol extract gave four flavonoids (2-5), a cyclitol (6) and a cycloartane-type saponin (7). Highest antioxidant activity in DPPH $\left(\mathrm{IC}_{50}=67.90 \pm 0.57 \mathrm{lg} / \mathrm{ml}\right)$, ABTS $\left(\mathrm{IC}_{50}=11.30 \pm 0.09 \mathrm{lg} / \mathrm{ml}\right)$ and CUPRAC $(\mathrm{A} 0.50: 50.60 \pm 0.9$ $\mathrm{lg} / \mathrm{ml}$ ) determined in the ethyl acetate extract. Chloroform extract gave the best antibacterial activity against Staphylococcus aureus, Escherichia coli and Pseudomonas aeruginosa, each with $80 \mathrm{lg} / \mathrm{ml}$ MIC values. The n-butanol extract resulted in higher phagocytic activity. However, many Astragalus species have not been screened their phytochemical compositions and biological activities.

In our previous study, aerial parts and root extracts of A. elongatus subsp. nucleiferus were analysed for their anticancer, antiproliferative and lactate dehydrogenase releasing effects (Sekeroglu et al., 2019, in press). Considering our previous results, we aimed to investigate total polyphenolic contents, in vitro antioxidant activities and neuroprotective potentials of ethanol and water extracts of the aerial parts and roots of Astragalus neurocarpus (AN) in the current research. Although, there is considerable evidence about pharmacological properties and traditional uses of Astragalus species, there has been no study so far determining biological activities of aerial parts and root extracts from AN. From this point of view, the results presented in this research could be the first report for the literature.

\section{Materials and Methods}

\subsection{Plant material}

The plant samples, roots and aerial parts, used in laboratory analyses were collected from Gaziantep (Turkey) during the months of April - May 2017. The plant samples were taxonomically identified by a senior taxonomist, Fatih Yayla, from the Department of Biology, Gaziantep University (Gaziantep, Turkey). The herbarium voucher (herbarium number: GAUN1708) was deposited at the Department of Biology, Gaziantep University, Turkey.

\subsection{Preparation of plant extracts}

AN samples were dried under the shade at laboratory conditions and powdered individually as aerial and root parts before the extraction. Each plant parts were extracted with ethanol (EtOH) and distilled water $\left(\mathrm{dH}_{2} \mathrm{O}\right)$ by the method of maceration as described in our previous publication (Gezici and Sekeroglu, 2019b; Gezici, 2019). After maceration period, plant samples were filtered and EtOH was evaporated under vacuum using a rotary evaporator, and then the extracts were kept at $4{ }^{\circ} \mathrm{C}$ until further analysis. Extract yields of the EtOH and $\mathrm{dH}_{2} \mathrm{O}$ extracts from the aerial parts and roots of $\mathrm{AN}$ are given as $\mathrm{w} / \mathrm{w} \%$ in Table 1.

\subsection{Total phenol and flavonoid contents}

Phenolic compounds in total were determined in accordance with slightly modified Folin-Ciocalteau's method (Singleton and Rossi, 1965; Gezici and Sekeroglu, 2019b). Absorption was measured at $760 \mathrm{~nm}$ at a using a 96-well microplate reader (Versa Max Molecular Devices, USA). Total flavonoid content of the extracts was calculated by Aluminum Chloride Colorimetric method (Woisky and Salatino,
1998; Gezici and Sekeroglu, 2019b). A number of dilutions of quercetin were obtained to prepare a calibration curve. Absorbance of the reaction mixtures was measured at wavelength of $415 \mathrm{~nm}$ with a using a 96-well microplate reader (VersaMax Molecular Devices, USA). The total phenol and flavonoid contents of the extracts were expressed as gallic acid and quercetin equivalents ( $\mathrm{mg}$ $\mathrm{g}^{-1}$ extract), respectively.

\subsection{Antioxidant activity analyses}

Antioxidant activities of the extracts were performed using in vitro methods including 2,2-diphenyl-1-picrylhydrazyl (DPPH), 2,2'azino-bis (3-ethylbenzothiazoline-6-sulphonic acid) (ABTS), ferric reducing antioxidant power (FRAP), and cupric ion reducing capacity (CUPRAC) (Chaturvedi, 2012; Gezici et al., 2017; Sekeroglu et al., 2017; Gundogdu et al., 2018; Gezici and Sekeroglu, $2019 \mathrm{~b}$ ). The extracts and commercial antioxidant standards were dissolved in DMSO at different concentrations, ranging from $100 \mu \mathrm{g}$ $\mathrm{ml}^{-1}$ to $1000 \mu \mathrm{g} \mathrm{ml}^{-1}$ for the antioxidant assays.

\subsection{Enzyme inhibition assays}

Neuroprotective activities of the extracts were evaluated against AChE (acetylcholinesterase), BChE (butyrylcholinesterase), and TYR (tyrosinase) in the current study. For the enzyme inhibition assays, the extracts were dissolved in DMSO at different concentrations, ranging from $100 \mu \mathrm{g} \mathrm{ml}^{-1}$ to $800 \mu \mathrm{g} \mathrm{ml}^{-1}$. The percentage of enzyme inhibition was calculated as following equation:

$$
\begin{aligned}
& \text { Percent of enzyme inhibition }(\%)=\left[\left(\mathrm{Abs}_{\text {control }}-\mathrm{Abs}_{\text {sample }}\right) /\right. \\
& \left.\mathrm{Abs}_{\text {control }} \times 100\right]
\end{aligned}
$$

\subsubsection{AChE and BChE inhibitory activity}

$\mathrm{AChE}$ and BChE inhibitory activity of the samples was measured by slightly modified spectrophotometric method of Ellman et al. (1961). Electric eel AChE (EC 3.1.1.Sigma, St. Louis, MO, USA) and horse serum BChE (EC 3.1.1. Sigma, St. Louis, 7 MO, USA) were used, while acetylthiocholine iodide and butyrylthiocholine chloride (Sigma, St. Louis, MO, USA) were employed as substrates of the reaction. 5,5'-Dithio-bis (2-nitrobenzoic) acid (DTNB, Sigma, St. Louis, MO, USA) was used for the measurement of the anticholinesterase activity. All reagents, conditions and calculations were same as described in our previous publication (Senol et al., 2018; Gezici and Sekeroglu, 2019b), and the final concentration of the tested samples was adjusted to $800 \mu \mathrm{g} \mathrm{ml}^{-1}$. Galanthamine hydrobromide (Sigma, St. Louis, MO, USA) was employed as the reference anti-cholinesterase, and the final concentration of the reference was adjusted to $100 \mu \mathrm{g} \mathrm{ml}^{-1}$.

\subsubsection{TYR inhibitory activity}

The modified dopachrome method with L-DOPA as substrate was used for determination the inhibition of tyrosinase (EC 1.14.1.8.1, $30 \mathrm{U}$, mushroom tyrosinase, Sigma) (Sekeroglu et al., 2012). $\alpha$ Kojic acid (Sigma, St. Louis, MO, USA) was used as the reference, and the final concentration of the tested samples and reference was adjusted to $800 \mu \mathrm{g} \mathrm{ml}^{-1}$ and $100 \mu \mathrm{g} \mathrm{ml}^{-1}$, respectively.

\subsection{Data analysis}

The data were taken from three independent experiments, and expressed as mean and standard deviation of mean (Mean $\pm \mathrm{SD}$ ). The measurements and calculations were evaluated by using Softmax PRO 4.3.2.LS software. $p$ value of $<0.05$ was considered to be 
statistically significant, $p<0.01$ and $p<0.001$ were considered to be very significant.

\section{Results}

\subsection{Total phenolicand flavonoid contents}

Total phenolicand flavonoid compositions of the extracts were identified spectrophotometrically in the current research. Gallic acid $(\mathrm{GA})$ and quercetin $(\mathrm{Q})$ equivalent were used as commercial standards for total phenolic and flavonoid contents, and the results were presented in Table 1.

Table 1: Extraction yields (w/w\%) and total polyphenolic contents of A. neurocarpus extracts

\begin{tabular}{|c|c|c|c|c|}
\hline \multirow{2}{*}{$\begin{array}{l}\text { Plant } \\
\text { part }\end{array}$} & \multirow{2}{*}{$\begin{array}{c}\text { Extract } \\
\text { type }\end{array}$} & \multirow{2}{*}{$\begin{array}{c}\text { Extract } \\
\text { yield } \\
(w / w \%)\end{array}$} & \multicolumn{2}{|c|}{ Total polyphenolic content ${ }^{a}$} \\
\hline & & & TPC $^{\text {a,b }}$ & TFC $^{\mathrm{a}, \mathrm{c}}$ \\
\hline \multirow[t]{2}{*}{ Aerial } & $\mathrm{OH}$ & 2.62 & $117.15 \pm 1.06$ & $179.34 \pm 1.02$ \\
\hline & $\mathrm{dH}_{2} \mathrm{O}$ & 2.58 & $91.34 \pm 0.84$ & $108.22 \pm$ \\
\hline \multirow[t]{2}{*}{ Root } & $\mathrm{EtOH}$ & 2.34 & $102.84 \pm 0.12$ & $49.73 \pm 1.56$ \\
\hline & $\mathrm{dH}_{2} \mathrm{O}$ & 2.21 & $110.75 \pm 1.68$ & $42.08 \pm 0.73$ \\
\hline
\end{tabular}

aThe values were expressed as Mean \pm standard deviation $(n=3)$. 'TPC: total phenolic content; mg equivalent of gallic acid (GAE) per g extract.

'TFC: total flavonoid content; mg equivalent of quercetin (QE) per $g$ extract.

According to polyphenolic contents of AN extracts, EtOH extract obtained from aerial part of the plant was found to have the richest in total phenols and flavonoids quantities $(117.15 \pm 1.06 \mathrm{mg} / \mathrm{g}$ extract, as GAE and $179.34 \pm 1.02 \mathrm{mg} / \mathrm{g}$ extract as QE). In addition, $\mathrm{dH}_{2} \mathrm{O}$ extract prepared from the aerial parts of the plant was demonstrated the lowest amount of total phenol content (91.34 \pm $0.84 \mathrm{mg} / \mathrm{g}$ extract as GAE), whereas $\mathrm{dH}_{2} \mathrm{O}$-root extract of the plant was showed the lowest total flavonoid content $(42.08 \pm 0.73 \mathrm{mg} / \mathrm{g}$ extract, as QE) (Table 1).

\subsection{Antioxidant activity results}

Free radical scavenging activities of AN extracts were assessed against DPPH and ABTS radicals, and the results were given as inhibition (\%) \pm standard deviation (Table 2). As presented in the Table 2, all the extracts displayed higher ABTS scavenging effects as compared to the DPPH scavenging effects at the tested concentrations. The highest DPPH scavenging activity was found to belong to the EtOH extract obtained from the aerial part (82.51 \pm $1.64 \%$ inhibition), whilst the highest ABTS scavenging activity was determined in the $\mathrm{dH}_{2} \mathrm{O}$ extract obtained from aerial part of the plant $(94.01 \pm 1.16 \%$ inhibition), followed by the EtOH-aerial part extract $(88.96 \pm 0.34 \%$ inhibition).

In the presented research, the AN extracts were also tested for their reducing power capacities on FRAP and CUPRAC. Almost, all the extracts obtained from different parts of A. neurocarpus exerted remarkable ferric reducing antioxidant power (FRAP), and moderate cupric ion reducing antioxidant power (CUPRAC) capacities, as summarized in the Table 3 with respect to their absorbance values \pm standard deviation (Table 3). However, a remarkable variation was not observed in the FRAP values of the extracts, in which the $\mathrm{dH}_{2} \mathrm{O}$ extract of aerial part from AN possessed the highest FRAP value, closely followed by root-EtOH extract of the plant (3.372 \pm 0.082 and $3.236 \pm 0.041$, respectively). Among the tested extracts, the EtOH extract of aerial part was determined to have the highest CUPRAC value $(1.095 \pm 0.036)$. In all cases, the extracts prepared from the aerial parts of the plant exerted higher antioxidant activity than those of the root extracts (Table 2 and Table 3).

Table 2: Free radical scavenging activities of A. neurocarpus extracts at $1000 \mu \mathrm{g} \mathrm{ml}-1$

\begin{tabular}{|l|c|c|c|}
\hline Plant part & Extract type & DPPH $^{\mathbf{a}}$ & ABTS $^{\mathbf{a}}$ \\
\hline Aerial & $\mathrm{EtOH}$ & $82.51 \pm 1.64 * * *$ & $88.96 \pm 0.34 * * *$ \\
& $\mathrm{dH}_{2} \mathrm{O}$ & $67.40 \pm 1.01 * *$ & $94.01 \pm 1.16 * * *$ \\
Root & $\mathrm{EtOH}$ & $46.08 \pm 0.52 * * *$ & $57.92 \pm 0.09 * *$ \\
& $\mathrm{dH}_{2} \mathrm{O}$ & $33.61 \pm 0.49 * *$ & $81.36 \pm 0.58 * * *$ \\
Ascorbic acid & & $72.94 \pm 0.06$ & - \\
Trolox $^{\mathrm{c}}$ & & - & $76.28 \pm 0.15$ \\
\hline
\end{tabular}

${ }^{a}$ The values were given as inhibition $(\%) \pm$ standard deviation.

${ }^{\mathrm{b}}$ Ascorbic acid is a commercial standard for DPPH assay.

'Trolox is a commercial standard for ABTS assay.

$*^{*} p$ value of $<0.01$; *** $p$ value of $<0.001$

Table 3: Reducing power capacities of A. neurocarpus extracts at $1000 \mu \mathrm{g} \mathrm{ml}^{-1}$

\begin{tabular}{|l|c|c|c|}
\hline Plant part & $\begin{array}{c}\text { Extract } \\
\text { type }\end{array}$ & FRAP $^{a}$ & CUPRAC $^{a}$ \\
\hline Aerial & $\mathrm{EtOH}$ & $3.182 \pm 0.006 * * *$ & $1.095 \pm 0.036 * * *$ \\
Root & $\mathrm{dH}_{2} \mathrm{O}$ & $3.372 \pm 0.082 * *$ & $0.576 \pm 0.102 * *$ \\
& $\mathrm{EtOH}$ & $3.236 \pm 0.041 * *$ & $0.324 \pm 0.085 * * *$ \\
$\mathrm{drol}_{2} \mathrm{O}$ & $3.173 \pm 0.010 * * *$ & $0.301 \pm 0.002 * * *$ \\
Chlorogenic $^{\mathrm{b}}$ & & -- & $2.136 \pm 0.008$ \\
acid $^{\mathrm{c}}$ & & $3.497 \pm 0.001$ & -- \\
\hline
\end{tabular}

aThe values were given as absorbance values \pm standard deviation.

${ }^{\mathrm{b}}$ Trolox is a commercial standard for CUPRAC assay.

${ }^{\mathrm{c}}$ Chlorogenic acid is a commercial standard for FRAP assay.

$* *$ p value of $<0.01$; ***p value of $<0.001$

\subsection{Enzyme inhibition results}

Neuroprotective activity of the extracts obtained from different parts of AN were evaluated through enzyme inhibition assays on acetylcholinesterase (AChE) and butyrylcholinesterase (BChE), and tyrosinase (TYR) enzymes at 100, 200, 400, and $800 \mu \mathrm{g} \mathrm{ml}^{-1}$ concentrations. As can be seen in Figure 1, the AN extracts were inhibited $\mathrm{AChE}$ and $\mathrm{BChE}$ enzymes from moderate level to high level, in which the higher cholinesterase inhibitory activity was observed against $\mathrm{AChE}$, compared to $\mathrm{BChE}$, whilst they did not demonstrate significantly inhibition against TYR enzyme at the tested concentrations. 


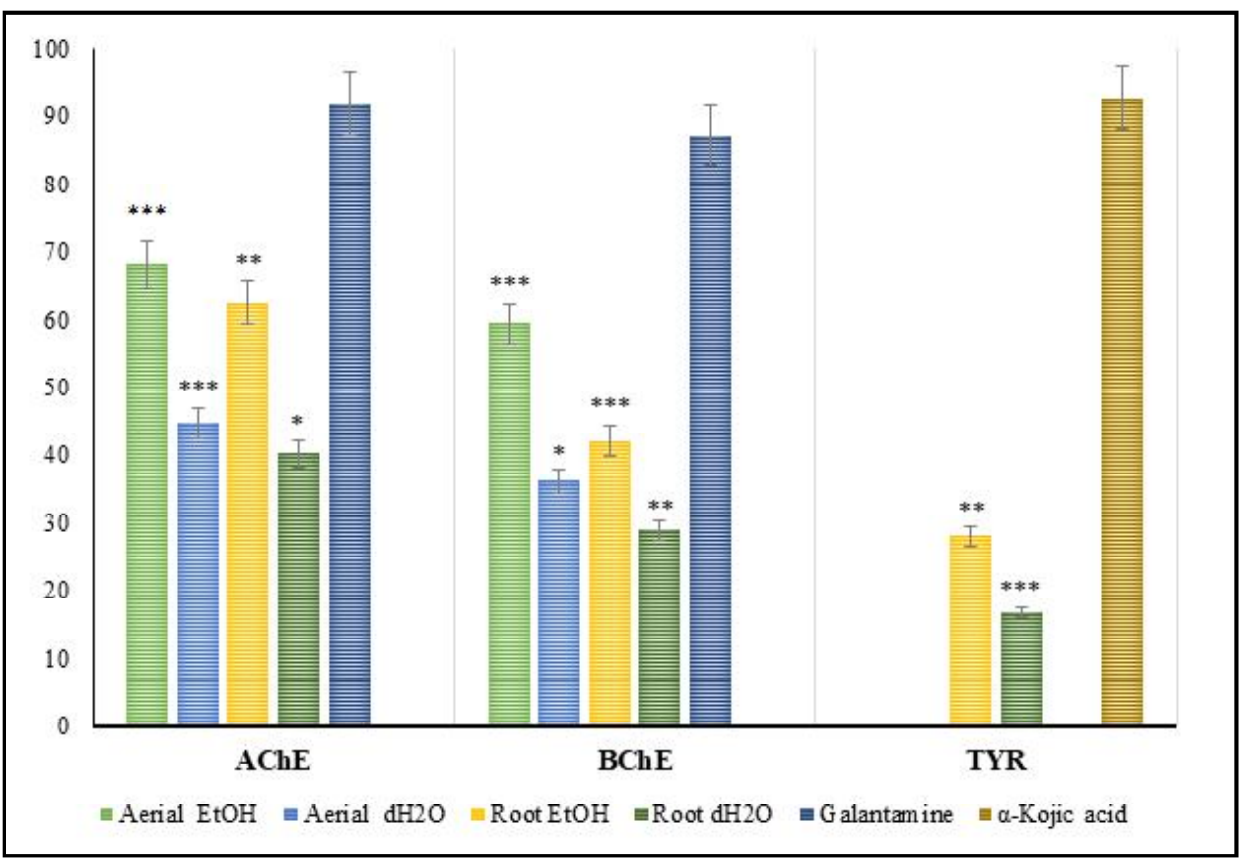

Figure 1: Enzyme inhibition capacities of A. neurocarpus extracts against AChE, BChE and TYR.

[The values were presented as inhibition $(\%) \pm$ standard deviation] [* $p$ value of $<0.05 ; * * p$ value of $<0.01 ; * * * p$ value of $<0.001$ ]

Table 4: Neuroprotective potentials of A. neurocarpus extracts against AChE, BChE and TYR at $800 \mu \mathrm{g} \mathrm{ml}^{-1}$

\begin{tabular}{|c|c|c|c|c|}
\hline \multirow[b]{2}{*}{ Plant part } & \multirow[b]{2}{*}{ Extract type } & \multicolumn{3}{|c|}{$\%$ Inhibition $\pm \mathrm{SD}^{\mathrm{a}}$} \\
\hline & & $\mathrm{AChE}$ & BChE & TYR \\
\hline \multirow[t]{2}{*}{ Aerial } & $\mathrm{EtOH}$ & $68.14 \pm 0.03 * * *$ & $59.44 \pm 1.02 * * *$ & $--^{d}$ \\
\hline & $\mathrm{dH}_{2} \mathrm{O}$ & $44.68 \pm 0.12 * * *$ & $36.15 \pm 0.06 *$ & $-{ }^{\mathrm{d}}$ \\
\hline \multirow[t]{2}{*}{ Root } & $\mathrm{EtOH}$ & $62.50 \pm 0.60 * *$ & $42.10 \pm 0.79 * * *$ & $28.03 \pm 0.10 * *$ \\
\hline & $\mathrm{dH}_{2} \mathrm{O}$ & $40.26 \pm 1.14 *$ & $28.94 \pm 0.58 * *$ & $16.84 \pm 0.08 * * *$ \\
\hline \multirow{2}{*}{\multicolumn{2}{|c|}{$\begin{array}{l}\text { Galantamine }^{\mathrm{b}} \\
\alpha-\text { Kojic acid }^{\mathrm{c}}\end{array}$}} & $91.86 \pm 0.72$ & $87.14 \pm 0.35$ & -- \\
\hline & & -- & -- & $92.75 \pm 1.60$ \\
\hline
\end{tabular}

${ }^{a}$ The values were given as inhibition $(\%) \pm$ standard deviation $(n=3)$.

${ }^{\mathrm{b}}$ Galantamine is a commercial standard for AChE and BChE enzymes

c á-Kojic acid is a commercial standard for TYR enzyme.

${ }^{\mathrm{d}}$ No inhibitory activity.

$*$ p value of $<0.05 ; * *$ p value of $<0.01 ; * * *$ p value of $<0.001$

As consistent with the total polyphenolic quantities of the extracts, enzyme inhibitory potentials of the tested extracts on cholinesterase enzymes were resulted in the superiority of the EtOH extracts from the aerial part $(68.14 \pm 0.03 \%)$ inhibition on $\mathrm{AChE}$, and (59.44 $\pm 1.02 \%)$ inhibition on $\mathrm{BChE}$, respectively. In the contrary the cholinesterase enzyme inhibition, the extracts obtained from the aerial parts of the plant were found inactive against TYR enzyme, while root- $\mathrm{dH}_{2} \mathrm{O}$ extracts of the plant were exerted $16.84 \pm 0.08 \%$, the lowest TYR enzyme inhibition at $800 \mu \mathrm{g} \mathrm{ml}^{-1}$ (Table 4).

\section{Discussion}

Some neurodegenerative mechanisms have been reported to cause pathogenesis of neurodegenerative diseases such as Alzheimer's disease (AD), Parkinson's disease (PD), amyotrophic lateral sclerosis
(ALS), prion diseases, etc. Of which, AD and PD are most common types of neurological disorders that lead to loss of memory and behaviour skills in elderly people (Sekeroglu et al., 2012; Gezici and Sekeroglu, 2019b). According to statistical data, there has been a great increase in AD and PD incidence worldwide (Harris, 2019). Nowadays, finding effective and safely therapy approaches are required to manage the high incidence of these diseases. From this point, the inhibition of key enzymes linked to the pathogenesis of the AD and PD diseases, used medicinal plant and plant-derived compounds are suggested as one of the most effective strategies. For example, inhibition of acetylcholinesterase (AChE), involved in the acetylcholine hydrolysis, is the most accepted treatment strategy in $\mathrm{AD}$. On the other hand, butyrylcholinesterase $(\mathrm{BChE})$ also has been considered to be involved in the pathogenesis of $\mathrm{AD}$. 
Furthermore, AD and PD can be seen at the same, as reported by previous researches. Therefore, the inhibition of tyhrosinase (TYR) alongside cholinesterases (ChE) is of great importance for the treatment of these diseases as multitarget drug approaches (Sekeroglu et al., 2012; Roleira et al., 2015; Liu et al., 2018; Gezici and Sekeroglu, 2019b). In our ongoing researches on finding natural enzyme inhibitors, neuroprotective potentials of AN extracts through AChE, BChE and TYR enzyme inhibition were aimed to screen, combined with total polyphenolic contents, free radical scavenging activities and ion reducing power capacities in the presented work.

However, phenolic and flavonoid contents of AN extracts were analysed for the first time in the presented research. Previous researches about the phytochemical compositions of different Astragalus species reported to have their rich phenolic and flavonoid contents in free and glycosidic forms. In regards of chemical compositions of Astragalus species, A. membranaceus and A. mongholicus (A. membranaceus var. mongholicus) are the best known species that isolated and purified the polysaccharides which could be also responsible for their high antioxidant activity. In fact, rich polyphenolic contents contribute to the radical scavenging activity and reducing power capacities of the extracts, as reported for different plants by previous studies (Tang and Eisenbrand, 1992; Rios and Waterman, 1997; Senol et al., 2018; Gezici et al., 2017; Sekeroglu et al., 2017).

According to the antioxidant results, AN extracts were found to have great antioxidant potentials, which were consistent with previous research conducted to investigate antioxidant potentials of different Astragalus species such as A. membranaceus, A. mongholicus, and A. lentiginosus (Li, 1991; Shimizu et al., 1991; Kang et al., 1993). These may be due to the fact that rich secondary metabolites components especially certain flavonoids, saponins, polysaccharides of the Astragalus species, as described previously (Rios and Waterman, 1997; Block and Mead, 2003). On this basis, A. neurocarpus with both aerial and root part could offer significant benefit for management of the oxidative-stress related diseases.

Although, previous studies focused on revealing the chemical compositions of some Astragalus species, a few researches have been performed to screen neuroprotective potentials of the extracts and bioactive compounds isolated from Astragalus species (Rios and Waterman, 1997; Chan et al., 2009; Gulcemal et al., 2013; Ionkova et al., 2014). On the other hand, this research is the first work that screened neuroprotective potentials of the extracts obtained from the different part of A. neurocarpus. In the light of the findings of these results, a significant correlation was not determined between the antioxidant capacities and neuroprotective potentials of the extracts.

\section{Conclusion}

In the presented work, enzyme inhibitory potentials of different parts of AN were analysed through inhibition of the enzymes associated with pathogenesis of neurodegenerative diseases. The results revealed from the work that the extracts of AN have considerable amount of antioxidant activity as well as anticholinesterase and anti-tyrosinase activity. There has been suggestion that the plant species, especially root part of its would have considerable as a potential source in the treatment of Alzheimer's and Parkinson diseases for their inhibitory activity on the AChE, $\mathrm{BChE}$, and TYR enzymes, and also for its rich antioxidant capacity.
This is the first research conducted to evaluate neuroprotective potentials of the extracts of $\mathrm{AN}$, as well as polyphenolic content and antioxidant activity. The author suggest that further in vivo studies should be performed to ascertain neuroprotective potentials of the plant.

\section{Acknowledgments}

This study was financially supported by Scientific Research Project Unit of Kilis 7 Aralik University, Kilis-Turkey (Project code no: 1859LTP1). Authors would like to thank senior taxonomist, FatihYayla for his kind contribution to identify plant material, and Advanced Technology Application and Research Center, Medicinal and Aromatic Plants Laboratory for their technical support.

\section{Conflict of interest}

The authors declare that no conflict of interest exists in the course of conducting this research. Both the authors had final decision regarding the manuscript and the decision to submit the findings for publication.

\section{References}

Al-Qubaisi, M.; Rozita, R.; Yeap, S.K.; Omar,A.R. and Ali, A.M. (2011). Selective cytotoxicity of goniothalamin against hepatoblastoma HepG2 cells. Molecules, 16(4): 2944-2959. https://doi.org/10.3390/ molecules 16042944.

Biradar, D. P. (2015). Medicinal plants and phytomedicines. Ann. Phytomed., 4(1):1-5.

Block, K.I. and Mead, M.N. (2003). Immune system effects of echinacea, ginseng, and astragalus: A review. Integr. Cancer Ther., 2(3):247267. https://doi.org/10.1177/1534735403256419.

Chan, W.S.; Durairajan, S.S.K.; Lu, J.H.; Wang, Y.; Xie, L.X.;Kum, W.F. and Li, M. (2009). Neuroprotective effects of astragaloside IV in 6hydroxydopamine-treated primary nigral cell culture. Neurochem. Int., 55(6): 414-422.https://doi.org/10.1016/j.neuint.2009.04.012.

Chaturvedi, S.; Hemamalini, R. and Khare, S.K. (2012). Effect of processing conditions on saponin content and antioxidant activity of Indian varieties of soybean (Glycine max Linn.). Ann. Phytomed., 1(1): $62-68$

Denizli, N.; Horo, I.; Gülcemal, D.;Masullo, M.; Festa, M.; Capasso, A. andAlankus-Caliskan, O. (2014). Cycloartane glycosides from Astragalus plumosus var. krugianus and evaluation of their antioxidant potential. Fitoterapia, 92: 211-218. http://dx.doi.org/ $10.1016 /$ j.fitote. 2013.10 .018 .

Ellman, G.L.; Courtney, K.D.; Andres Jr, V. and Featherstone, R.M. (1961). A new and rapid colorimetric determination of acetylcholinesterase activity. Biochem. Pharmacol., 7:88-95. https://doi.org/10.1016/ 0006-2952(61)90145-9.

Gezici, S.;Sekeroglu, N. and Kijjoa, A. (2017). In vitro anticancer activity and antioxidant properties of essential oils from Populus alba L. and Rosmarinus officinalis L. from South Eastern Anatolia of Turkey. Ind. J. Pharm. Educ. Res., 51(3):498-503. https://doi.org/ 10.5530/ijper. $51.3 \mathrm{~s} .74$.

Gezici, S. and Sekeroglu, N. (2019a). Current perspectives in the application of medicinal plants against cancer: Novel therapeutic agents. Anticancer Agents Med. Chem., 19(1):101-111. https://doi.org/ 10.2174/1871520619666181224121004.

Gezici, S. and Sekeroglu, N. (2019b). Neuroprotective potential and phytochemical composition of acorn fruits. Ind. Crop. Prod.128: 13-17. https://doi.org/10.1016/j.indcrop.2018.10.082. 
Gezici, S. (2019). Anticancer, antiproliferative, lysosomal and lactate dehydrogenase inhibitory effects of fruit extracts from sumac (Rhuscoriaria L.) on human lung cancer cells. Acta Oncologica Turcica, 52(1):160-168. https://doi.org/10.5505/aot. 2019. 093266.

Gezici, S. (2018). Promising anticancer activity of lavender (Lavandu laangustifolia Mill.) essential oil through induction of both apoptosis and necrosis. Ann. Phytomed.,7(2):38-45. https:// doi.org/10.21276/ap.2018.7.2.55.

Gülcemal, D.; Masullo, M.; Napolitano, A.; Karayldnm, T.;Bedir, E.; AlankusCaliskan, O. and Piacente, S. (2013). Oleanane glycosides from Astragalus tauricolus: Isolation and structural elucidation based on a preliminary liquid chromatography-electrospray ionization tandem mass spectrometry profiling. Phytochem., 86:184194.http://dx.doi.org/10.1016/j.phytochem.2012.10.001.

Gundogdu, M.; Tunçtürk, M.; Berk, S.; Sekeroglu, N. and Gezici, S. (2018). Antioxidant capacity and bioactive contents of Mulberry species from Eastern Anatolia Region of Turkey. Ind. J. Pharm. Educ. Res.,52(4):96-101. https://doi.org/10.5530/ijper.52.4s.82.

Harris, R.E. (2019). Epidemiology of chronic disease: Global perspectives. Jones and Bartlett Publishers.

Ionkova, I.; Shkondrov, A.;Krasteva, I. and Ionkov, T. (2014). Recent progress in phytochemistry, pharmacology and biotechnology of Astragalus saponins. Phytochem. Rev., 13(2):343-374. http://dx.doi.org/ 10.1007/s1 1101-014-9347-3.

Iqbal, M. (2013). From medicine to phytomedicine. Ann. Phytomed., 2: $1-2$.

Kang, M.S.; Bowlin, T.L.; Vijay, I.K. and Sunkara, S.P. (1993). Accumulation of pentamannose oligosaccharides in human mononuclear leukocytes by action of swainsonine, an inhibitor of glycoprotein processing. Carbohydr. Res., 248:327-337.https://doi.org/10.1016/ 0008-6215(93)84138-V.

Labed, A.; Ferhat, M.; Labed-Zouad, I.;Kaplaner, E.; Zerizer, S.; VoutquenneNazabadioko, L.; AlabdulMagid, A.; Semra, Z.; Kabouche, A.; Kabouche, Z. and Öztürk, M. (2016). Compounds from the pods of Astragalus armatus with antioxidant, anticholinesterase, antibacterial and phagocytic activities. Pharm. Biol., 54(12):3026-3032. http:// dx.doi.org/10.1080/13880209.2016.1200632.

Li, X.Y. (1991). Immunomodulating Chinese herbal medicines. Mem. Inst. Oswaldo Cruz, 86:159-164.http://dx.doi.org/10.1590/S007402761991000600036 .

Liu, H.; Chen, S.;Guo, C.; Tang, W.; Liu, W. and Liu, Y. (2018). Astragalus polysaccharide protects neurons and stabilizes mitochondrial in a mouse model of Parkinson disease. Med. Sci. Monit., 24:51925199.http://dx.doi.org/10.12659/MSM.908021.

Mosmann, T. (1983). Rapid colorimetric assay for cellular growth and survival: Application to proliferation and cytotoxicity assays. J. Immunol. Methods, 65(1-2):55-63. https://doi.org/10.1016/00221759(83)90303-4.

Newman, D.J. and Cragg, G.M. (2016). Natural products as sources of new drugs from 1981 to 2014. J. Nat. Prod., 79(3):629-661. https:// doi.org/10.1021/acs.jnatprod.5b01055.

Ranjbar, M. and Mahmoudian, B. (2015). An overview on cytogenetics of the genus Astragalus subgenus Hypoglottis (Fabaceae). Caryologia, 68(2): 109-124. https://doi.org/10.1080/00087114.2015.10325 71 .

Rios, J.L. and Waterman, P.G. (1997). A review of the pharmacology and toxicology of Astragalus. Phytother. Res., 11(6):411-418.
Roleira, F.M.; Tavares-da-Silva, E.J.; Varela, C.L.; Costa, S.C.; Silva, T.; Garrido, J. and Borges, F. (2015). Plant derived and dietary phenolic antioxidants: Anticancer properties. Food Chem., 183:235-258. https://doi.org/10.1016/j.foodchem.2015.03.039.

Roleira, F.M; Varela, C.L.; Costa, S.C. and Tavares-da-Silva, E.J. (2018). Phenolic derivatives from medicinal herbs and plant extracts: Anticancer effects and synthetic approaches to modulate biological activity. Stud. Nat. Prod. Chem., 57:115-56. https://doi.org/ 10.1016/B978-0-444-64057-4.00004-1.

Sekeroglu, N.; Gezici, S.;Tanriover, C. and Yayla, F. (2019). Anticancer, antiproliferative and lactate dehydrogenase enzyme activities of Astragalus elongatus subsp. nucleiferus on human cancer cells. KSU J. Agric Nat., 22(4): in press.https://doi.org/10.18016/ ksutarimdoga.vi.569493.

Sekeroglu, N.; Senol, F.S.; Orhan, I.E.; Gulpinar, A.R.; Kartal, M. and Sener, B. (2012). In vitro prospective effects of various traditional herbal coffees consumed in Anatolia linked to neurodegeneration. Food Res. Int., 45:197-203. https://doi.org/10.1016/j.foodres.2011. 10.0088

Sekeroglu, N.; Urlu, E.; Kulak, M.; Gezici, S. and Dang, R. (2017). Variation in Total Polyphenolic Contents, DNA Protective Potential and Antioxidant Capacity from Aqueous and Ethanol Extracts in Different Plant Parts of Hypericumperforatum L. Ind. J. Pharm. Educ. Res.,51: 1-7. https://doi.org/10.5530/ijper.51.2s.43.

Senol, F.S.; Sekeroglu, N.; Gezici, S.; Kilic, E. and Orhan, I.E. (2018). Neuroprotective potential of the fruit (acorn) from Quercusc occifera L. Turk. J Agric. For., 42:82-87. https://doi.org/10.3906/ tar-1711-18.

Shao, B.M.; Xu, W.; Dai, H.; Tu, P.; Li, Z. and Gao, X.M. (2004). A study on the immune receptors for polysaccharides from the roots of Astragalus membranaceus, a Chinese medicinal herb. Biochem. Biophys. Res. Commun., 320(4):1103-1111. https://doi.org/ 10.1016/j.bbrc.2004.06.065.

Shimizu, N.; Tomoda, M.;Kanari, M. and Gonda, R. (1991). An acidic polysaccharide having activity on the reticuloendothelial system from the root of Astragalus mongholicus. Chem. Pharm. Bull., 39(11): 2969-2972.https://doi.org/10.1248/cpb.39.2969.

Singleton, V.L. and Rossi, J.A. (1965). Colorimetry of total phenolics with phosphomolybdic-phosphotungstic acid reagents. Am. J. Enol. Vitic., 16:144-158.

Strober, W. (2015). Trypan blue exclusion test of cell viability. Curr. Protoc. Immunol., 111(1):A3.B.1-A3.B.3. https://doi.org/10.1002/ 0471142735 .ima03bs111.

Tang, W. and Eisenbrand, G. (2013). Chinese drugs of plant origin: Chemistry, pharmacology, and use in traditional and modern medicine. Springer Science \& Business Media, pp:191-197.

Wang, L.X. and Han, Z.W. (1992). The effect of Astragalus polysaccharide on endotoxin-induced toxicity in mice. Acta Pharm. Sin., 27(1):5-9.

Woisky, R.G. and Salatino, A. (1998). Analysis of propolis: Some parameters and procedures for chemical quality control. J. Apic Res., 37:99105. https://doi.org/10.1080/00218839.1998.11100961.

Yalcin, F.N.; Piacente, S.; Perrone, A.; Capasso, A.; Duman, H. and Çalis, I. (2012). Cycloartane glycosides from Astragalus stereocalyx Bornm. Phytochem.,73:119-126. https://doi.org/10.1016/j.phytochem. 2011.09 .011 .

Zhang, Y.D.; Shen, J.P.; Zhu, S.H.; Huang, D.K.; Ding, Y. and Zhang, X.L. (1992). Effects of Astragalus (ASI, SK) on experimental liver injury. Acta Pharm. Sin., 27(6):401-406.

Citation: Nazim Sekeroglu and Sevgi Gezici (2019). Astragalus neurocarpus Bioss. as a potential source of natural enzyme inhibitor associated with Alzheimer's and Parkinson diseases along with its rich polyphenolic content and antioxidant activities. Ann. Phytomed., 8(1):82-87. 